\section{JURNAL EKONOMI EFEKTIF}

ISSN : $2622-8882$, E-ISSN : 2622-9935

Jurnal Ekonomi Efektif, Vol. 2, No. 3, April 2020

@Prodi Manajemen Fakultas Ekonomi Universitas

Pamulang

\title{
ANALISIS GAYA KEPEMIMPINAN KEPALA DESA DALAM PENGEMBANGAN DESA CIDOKOM GUNUNG SINDUR KABUPATEN BOGOR
}

\author{
Denok Sunarsi ${ }^{*}$, Hadi Winata ${ }^{2}$, Gunartin $^{3}$, Paeno $^{4}$ \\ Universitas Pamulang \\ denoksunarsi@unpam.ac.id*
}

\begin{abstract}
ABSTRAK
Tujuan penelitian ini untuk mengalisis gaya kepemimpinan kepala desa Cidokom dalam melaksanakan kepemimpinannya yang diamanahkan oleh masyarakat desa melalui pemilihan umum. Hasil observasi, pengamatan langsung dan wawancara dengan masyarakat desa, diketahui bahwa perkembangan desa cenderung statis dilihat dari belum adanya jaringan komunikasi modern, transportasi publik belum teersedia secara memadai dan tingginya tingkat kriminalitas serta lambatnya pelayanan birokrasi. Metode penelitian yang digunakan adalah kualitatif deskriptif, dengan pendekatan observasi langsung pada intrumen kunci untuk mendapatkan data yang akurat. Hasil penelitian didasarkan pada perolehan data pendukung seperti jumlah penduduk yang ditinjau dari jenjang pendidikan dan status social ekonomi dari mata pencaharian yang mana hal ini masih menunjukkan rendahnya tingkat pendidikan di Desa Cidokom dan tentunya juga rendahnya kualitas SDM yang ditunjukkan pada masih tingginya jumlah penduduk yang berstatus pengurus rumah tangga.
\end{abstract}

\section{Kata Kunci: Gaya Kepemimpinan, Pengembangan, Desa.}

\section{ABSTRACT}

The purpose of this study was to analyze the leadership style of the Cidokom village head in carrying out his leadership which was mandated by the village community through general elections. The results of observations, direct observations and interviews with village communities, it is known that village development tends to be static as seen from the absence of modern communication networks, public transportation is not yet available adequately and the high level of crime and slow bureaucratic services. The research method used is descriptive qualitative, with a direct observation approach to key instruments to obtain accurate data. The results of the study are based on obtaining supporting data such as the number of people in terms of education level and the socioeconomic status of livelihoods, which still shows the low level of education in Cidokom Village and of course the low quality of human resources which is shown in the high number of people who have management status. household.

Keywords: Leadership Style, Development, Village. 


\section{PENDAHULUAN}

\section{A. Latar Belakang Masalah}

Desa Cidokom merupakan salah satu desa dari Kecamatan Gunung Sindur Kabupaten Bogor Jawa Barat, dengan batas wilayah Desa/Kelurahan sebelah Utara adalah Desa Padurenan, sebelah Selatan Desa Waru Jaya, sebelah Timur Desa Curug dan sebelah Barat Desa Cibinong. Masyarakat Desa Cidokom sebagian besar bermata pencaharian bertani dan berladang. Ditinjau dari status wilayahnya Desa Cidokom tergolong katagori desa madya. Artinya, merupakan desa menjadi maju yang memiliki sumber daya sosial, ekonomi dan ekologi tetapi pengelolaannya belum optimal untuk peningkatan kesejahteraan desa, kualitas hidup manusia dan menanggulangi kemiskinan. Untuk itu Desa Cidokom membutuhkan perhatian khusus untuk melakukan pengembangan desa secara berkelanjutan dan mandiri. Yang tentunya membutuhkan pemimpin yang mampu menggerakan seluruh elemen dan pemberdayaan potensi yang dimiliki untuk pengembangan desa menuju katagori desa maju dan mampu menjadi desa mandiri.

Di era industri 4.0 seperti sekarang ini sudah seharusnya memanfaatkan perkembangan teknologi informasi dan komunikasi, untuk memberikan layanan informasi kepada masyarakat dengan cepat dan akurat. Dengan gerakan layanan terpadu diharapkan layanan publik dapat berjalan lancar dan memuaskan. Namun, pada realisasinya Desa Cidokom masih jauh memuaskan dalam memberikan layanan publik. Salah satu faktor penghambat pengembangan desa yaitu birokrasi dalam kelembagaan organisasi yang masih lama dalam memberikan pelayanan. Hal ini dapat ditunjukkan melalui belum adanya jaringan internet, transportasi publik belum tersedia dengan memadai dan tingginya tingkat kriminalitas. Melihat kondisi yang telah dipaparkan maka sangat dibutuhkan transformasi yang terencana dan terukur, untuk memberikan solusi dari problem statement yang menjadi ciri kelemahan dari organisasi pemerintah secara umum, yang dipandang perlu meningkatkan responsivitas, transparansi, membangun sistem dan mekanisme yang accessible sehingga memungkinkan adanya "checks and balances".

Menurut Hasibuan (2015:13) berpendapat bahwa kepemimpinan adalah seseorang yang mempergunakan wewenang dan kepemimpinannya untuk mengarahkan orang lain serta bertanggung jawab atas pekerjaan orang tersebut dalam mencapai suatu tujuan. Danang Sunyoto (2015:34), berpendapat bahwa kepemimpinan adalah sebuah organisasi sifat dan sikap kepemimpinan seseorang pemimpin untuk mempengaruhi orang lain sangat menentukan di dalam mencapai tujuan organisasi.

Transformasi organisasi pemerintah dipengaruhi oleh gaya kepemimpinan seorang pemimpin. dan struktur organisasi yang dikembangkan sehingga adaktif terhadap perubahan yang dapat meningkatkan kecepatan birokrasi dalam memberikan layanan masyarakat.

Desa Cidokom cenderung statik, dibanding dengan desa-desa sekitarnya yang sudah mulai melek IPTEK, tentu hal ini tidak lepas dari gaya kepemimpinan Kepala Desa yang merupakan pimpinan tertinggi desa.

Desa Cidokom di pimpin oleh seorang kepala desa yang diangkat melalui sistem pemilihan umum dalam kurun waktu lima tahun sekali. Berdasarkan hasil observasi pra riset yang dilakukan penulis, melihat dan mengamati keadaan desa, penduduk, aparat desa dan pimpinan desa dalam hal ini seorang kepala desa, penulis menemukan banyak permasalahan terkait gaya kepemimpinan kepala desa. Dimana kepala desa cenderung membuat keputusan secara langsung, aparat desa berserta unsur-unsur pendukung desa dilihat belum maksimal menjalankan tugas, karang taruna dan lembaga swadaya 
masyarakan tidak terlihat geliatnya untuk membangun, memajukan dan mengembangkan desa sesuai dengan perkembangan zaman.

Dalam hal ini diperlukan seorang pimpinan yang dapat menggerakan seluruh elemen desa untuk memejukan desa dan mengembangkan masyarakat desa dari segala sektor diantara nya pendidikan para remaja melalui karang taruna, pemberdayaan perempuan dan peningkatan pendapatan masyarakat desa melalui pemenfaatan teknologi informasi

\section{METODE PENELITIAN}

Metode penelitian yang digunakan adalah kualitatif deskriptif, dengan pendekatan observasi langsung pada intrumen kunci untuk mendapatkan data yang akurat

Teknik analisa data adalah mendeskripsikan teknik analisis apa yang digunakan oleh peneliti untuk menganalisa data yang telah dikumpulkan (Sanusi Anwar, 2011). Pada penelitian ini peneliti menggunakan metode analisa statistik deskriptif, yaitu suatu analisa yang dimaksudkan untuk menjelaskan data dari satu variabel yang diteliti.

Pada metode ini, deskriptif yang sering digunakan untuk mendeskripsikan data hasil penelitian. Dalam hal ini penulis ingin menganalisa dan mendeskripsikan gaya kepemimpinan Kepala Desa Cidokom Gunung Sindur Kabupaten Bogor. Tahapan teknik analisis data, yaitu:

a. Tahap Pengumpulan data

Tahap mengumpulkan data di lokasi penelitian dengan melakukan observasi, wawancara, dan dokumentasi dengan menentukan strategi pengumpulan data yang dipandang tepat dan relevan.

b. Tahap Reduksi data,

Reduksi data merupakan proses seleksi, pemfokusan, pengabstrakan, transformasi data kasar yang ada di lapangan langsung, dan diteruskan pada waktu pengumpulan data, dengan demikian reduksi data dimulai sejak peneliti memfokuskan wilayah penelitian.

c. Tahap Penyajian data

Penyajian data merupakan rangkaian organisasi informasi yang memungkinkan penelitian dilakukan. Penyajian data diperoleh berbagai jenis, jaringan kerja, keterkaitan kegiatan atau tabel.

d. Tahap Penarikan kesimpulan,

Penarikan kesimpulan yaitu dalam pengumpulan data, peneliti harus mengerti dan tanggap terhadap sesuatu yang diteliti langsung di lapangan dengan menyusun polapola pengarahan.

\section{HASIL PENELITIAN DAN PEMBAHASAN}

Dalam pelaksanaan kinerja penyelenggaraan pemerintahan desa, pimpinan tentunya mempunyai rencana suatu program yang akan dilaksanakan baik dalam kurun waktu 1 (satu) tahun maupun dalam kurun waktu 6 (enam) tahun selama memegang Jabatan Kepala Desa. Sedangkan rencana dan program kerja bidang pemerintahan desa selama kurun waktu 1 (satu) tahun anggaran secara umum memenuhi program kerja sebagai berikut :

1. Membuat Produk Hukum Desa yang mengacu kepada ketentuan peraturan perundangundangan yang berlaku untuk dijadikan salah satu acuan kerja bidang penyelenggaraan pemerintahan desa;

2. Melaksanakan rekapitulasi perkembangan laju pertumbuhan jumlah penduduk;

3. Melaksanakan catur tertib pertanahan;

4. Melaksanakan manajemen pemerintahan terhadap SDM rekrutmen perangkat desa dan Lembaga Pemerintahan Desa berdasarkan kebutuhan dan ketentuan yang berlaku; 
5. Meningkatkan penyelenggaraan ketentraman dan ketertiban wilayah dan lingkungan serta kewaspadaan terhadap gangguan keamanan;

6. Melaksanakan pembinaan peningkatan SDM terhadap Aparatur Lembaga Pemerintahan Desa dan Lembaga Kemasyarakatan Desa;

Dari rencana kegiatan yang telah diprogramkan, dalam rangka pencapaian tujuan dan sasaran pembangunan dalam bidang penyelenggaraan pemerintahan desa, pimpinan desa tentunya tidak akan mampu mengemban tugas sendiri tanpa sinergi dari masyarakat dan dinas/instansi yang terkait. Perencanaan pengembangan memang telah dilaksanakan sebagian, tetapi belum menunjukkan hasil yang signifikan sesuai tujuan pengembangan yaitu menjadi desa mandiri dalam mensejahterakan masyarakat.

Sedangkan berdasarkan mata pencaharian, data yang diperoleh menunjukkan prosentase sebagai pengurus rumahtangga paling tinggi yaitu 19,85\% dari yang memiliki aktifitas bekerja sedang yang belum bekerja atau belum produkstif menunjukkan angka $53,55 \%$. Dari data tersebut masih perlunya perhatian khusus uapaya peningkatan kualitas SDM guna menuju desa mandiri, hal itu perlu peran optimal dari Kepala Desa dan aparat desa yang didukung oleh masyarakat setempat. Keberhasilan pengembangan tentu dipengaruhi oleh gaya kepemimpinan Kepala Desa sebagai orang nomor satu di pemerintahaan desa. Menjadi Kepala Desa tidak cukup hanya mengandalkan kekuasaannya dalam menjalankan pemeintahan desa, tetapi dibutuhkan sosok yang mampu menggerakkan seluruh elemen desa untuk bersama sama bersinerge membangun desanya secara berkelanjutan agar di masa yang akan datang nanti menjadi desa yang mandiri yang tidak tergantung pada desa lain atau pemerintah kabupaten setempat.

Selain data di atas, Desa Cidokom masih menunjukkan belum maksimalnya pengembangan, hal ini dapat ditunjukkan dengan beberapa infrastruktur yang rusak seperti pintu masuk dari jalan raya propinsi Tangerang Selatan - Bogor, sering terjadinya pemadaman tanpa jadual yang jelas, tidak stabilnya sinyal komunikasi dan aktifitas masyarakat yang cenderung massif, sehingga tampak banyaknya masyarakat yang belum beraktifitas bekerja.

Juga disampaikan oleh kepala desa bahwa berkaitan dengan penyelenggaraan Pemerintahan Desa Cidokom, Kepala Desa telah berusaha untuk melaksanakan tugas, fungsi, wewenang dan kewajiban sesuai dengan ketentuan Peraturan Perundang-undangan yang berlaku. Namun, disadari bahwa dalam pelaksanan tugas dan kinerja tersebut masih ada beberapa hal yang belum optimal, sehingga dapat dioptimalisasikan dan ditingkatkan pada masa yang akan datang

Gaya kepemimpinan yang sedikit tertutup memang berdampak kurang wearnya jajaran etruktural desa dengan masyarakat. Potensi masyarakat yang seharusnya menjadi kekuatan desa untuk melakukan pengembangan menjadi desa maju dan mandiri, karena kurang terbuka dan dominan pemerintahan desa seperti dinasti sebatas keluarga dan kerabatnya yang menjabat, hal ini akan mengurangi profesionalisme kerja. Akan sulit mendapatkan masukan dan kritikan yang membangun, apalagi melakukan perubahan seiring dengan perkembangan teknologi komunikasi dan informasi.

Hal ini didukung pleh penelitian sebelumnya yang menyatakan bahwa strategi pengembangan dapat dilakukan dengan pendekatan yang menjamin keseimbangan ekologi dan pertumbuhan ekonomi dengan perencanaan yang terpadu dan berkelanjutan serta berbasis masyarakat, yang didukung infrastuktur dan beberapa kebijakan seperti kebijakan perdagangan lintas batas (Rindukasih dan Karyanti, 2013). Juga didukung oleh hasil riset Syahza (2103), pengembangan pedesaan harus dilakukan dengan pendekatan yang sesuai dengan sifat dan cirinya. pengembangan pedesaan harus mengikuti empat upaya besar, dimana satu sama lain saling berkaitan dan merupakan strategi pokok pengembangan 
pedesaan, yaitu: memberdayakan ekonomi masyarakat desa, meningkatkan kualitas sumberdaya manusia pedesaan, pengembangan prasarana di pedesaan, dan membangun kelembagaan pedesaan baik yang bersifat formal maupun nonformal. Kelembagaan yang dibutuhkan oleh pedesaan adalah terciptanya pelayanan yang baik terutama untuk memacu perekonomian pedesaan demi terciptanya masyarakat desa yang sejahtera dan mandiri.

\section{PENUTUP}

\section{A. Kesimpulan}

Setelah dilakukan analisa terhadap hasil penelitian, dari program pengembangan desa yang telah dijalankan untuk mencapai tujuan pengembangan terdapat beberapa hal yang belum dicapai secara maksimal, hal ini didasarkan pada perolehan data pendukung seperti jumlah penduduk yang ditinjau dari jenjang pendidikan dan status social ekonomi dari mata pencaharian yang mana hal ini masih menunjukkan rendahnya tingkat pendidikan di Desa Cidokom dan tentunya juga rendahnya kualitas SDM yang ditunjukkan pada masih tingginya jumlah penduduk yang berstatus pengurus rumah tangga. Berikut disajikan demografi penduduk Desa Cidokom Kecamatan Gunungsindur Kabupaten Bogor.

\section{B. Saran}

Setelah melakukan penelitian ini, disarankan bagi pemerintah desa landasan pengambilan kebijakan dalam menentukan arah kebijakan percepatan pembangunan desa berkelanjutan untuk menjadi desa mandiri, perlu komitmen yang tinggi untuk mewujudkan desa mandiri berkelanjutan tidak sekedar assesment tetapi harus diwujudkan visi misi pemerintah desa dengan gaya kepemimpinan yang cocok dengan desa terkait yang ingin menjadikan Desa Cidokom Gunung Sindur Kabupaten Bogor sebagai desa mandiri berkelanjutan, dan menciptakan masyarakat yang makmur dan sejahtera.

\section{DAFTAR PUSTAKA}

Almasdi Syahza dan Suarman (2013). Strategi Pembangunan Daerah Tertinggal dalam Upaya Percepatan Pembangunan Ekonomi Pedesaan. Jurnal Ekonomi Pembangunan, Volume 14 Nomor 1, hlm. 126-139

D Sunarsi. (2020). Kepemimpinan Bisnis Strategik. Kota Serang: Desanta Muliavisitama

Handoko, T. Hani. 2014. Manajemen Personalia dan Sumber Daya Manusia. Yogyakarta: BPFE.

Hasibuan, Malayu, S.P, 2015. Manajemen Sumber Daya Manusia, Edisi Revisi, Bumi Aksara, Jakarta

Istiqomah Qodriani Fajrin dan Heru Susilo (2018) Pengaruh Gaya Kepemimpinan Terhadap Kinerja Karyawan Dengan Motivasi Kerja Sebagai Variabel Intervening (Studi pada Karyawan Pabrik Gula Kebon Agung Malang). Jurnal Administrasi Bisnis Vol. 61No. 4, Hal: $117-124$

Jamaludin, Agus. 2017. Pengaruh Gaya Kepemimpinan Terhadap Kinerja Karyawan Pada PT.Kaho Indahcitra Garment Jakarta, Journal of Applied Business and Economics Vol. 3 No. 3 Hal: 161-169.https://journal.lppmunindra.ac.id

Kartono, Kartini, 2015. Pemimpin dan Kepemimpinan. Jakarta : PT. Raja.

Radar Nusantara, 9 Oktober 2019, diakses 20 Maret 2020

Samsudin, Sadili. 2010. Manajemen Sumber Daya Manusia. Bandung : Pustaka Setia.

Siagian, 2018, Manajemen Sumber Daya Manusia, Jakarta, PT. Elek Media Kompetindo. Sugiyono, 2016. Metode Penelitian Kuantitatif, Kualitatif dan R\&D, Jakarta: Alfabeta, 
Sunarsi, D. (2014). Pengaruh Gaya Kepemimpinan, Motivasi dan Disiplin Kerja Terhadap Kinerja Pendidik (Doctoral dissertation, Universitas Pamulang).

Sunarsi, D. (2017). Pengaruh Kepemimpinan Dan Budaya Organisasi terhadap Kinerja Karyawan Pada Cabang Pembantu Bank DKI Pondok Labu-Jakarta Selatan. JENIUS, $1(2), 21$.

Sunarsi, D. (2018). Pengembangan Sumber Daya Manusia Strategik \& Karakterisrik Sistem Pendukungnya : Sebuah Tinjauan. Jurnal Ilmiah MEA (Manajemen, Ekonomi, \& Akuntansi), 2(3), 178 - 194.

Sunyoto. Danang S. 2015. Manajemen Sumber Daya Manusia Teori dan Aplikasi. Bandung: Alfabeta..

Syarifah Lailatis. 2018. Strategi Percepatan Pembangunan Daerah Berbasis Kearifan Lokal di Kecamatan Gunung Wungkal. Jurnal Religi volume XIV nomor 1 Juni 2018 hal 135 - 154 


\section{PANDUAN SINGKAT BAGI PENULIS JURNAL EFEKTIF}

Panduan penulisan ini dimaksudkan untuk menyeragamkan bentuk penulisan karya ilmiah yang dikirim penulis ke redaksi Jurnal Efektif, dengan panduan penulisan sebagai berikut :

1. Naskah ditulis dalam Bahasa Indonesia dengan Abstrak Bahasa Indonesia dalam bentuk Font 12" dengan ukuran 1 Spasi dengan intisari tidak lebih dari 250 kata disertai 3 atau 4 kata kunci (keyword).

Naskah berupa Softcopy program MS Word maksimal 15 Halaman termasuk tabel dan gambar, spasi 1.

2. Sistematika penulisan disusun dengan urutan sebagai berikut :

a) Judul, nama dan alamat email penulis/peneliti tunggal.

b) Abstrak dan intisari, keyword dan kata kunci, dibuat dengan 1 kolom.

c) Batang Tubuh :

1). Pendahuluan, termasuk didalamnya intisari permasalahan

2). Metode Penelitian

3). Hasil dan Pembahasan

4). Kesimpulan

5). Daftar Pustaka

3. Judul ditulis dalam bentuk font Times New Roman 14" dengan huruf besar kecil dicetak tebal dan ditempatkan ditengah halaman,, serta tidak lebih dari 18 kata.

4. Tulisan karya ilmiah dalam bentuk font Times New Roman 12" dengan ukuran spasi 1,0 spasi dalam bentuk normal.

5. Gambar diberi nomor dan keterangan, sedangkan tabel diberi nomor dan keterangan diatasnya sesuai dengan bab nya.

6. Penulisan persamaan matematika yang terdapat pada halaman naskah hendaknya menggunakan equation editor.

7. Daftar pustaka hanya memuat literature yang dirujuk dalam keterangan dan dicantumkan pada bagian akhir naskah.

8. Margin Normal, dan ukuran kertas A4.

9. Email Redaksi : denoksunarsi@unpam.ac.id / jurnaleffective@gmail.com 